This is an accepted version of an encyclopedia entry in Lowry, L. (ed.) (2017) The Sage International Encyclopedia of Travel and Tourism, London: Sage

\title{
National Tourism Offices
}

National Tourism Offices (NTOs) are the agencies responsible for the promotion and, sometimes, the management of the development of the tourism industry within a country. They will have a strong relationship with a government department or office, and will implement and monitor national tourism policy through a variety of means which can include research, influencing the tourism policy making process, destination marketing, tourism product development and the maintenance of national standards for the tourism industry. NTOs are almost always led by the public sector and will be governed within national public sector arrangements. However, NTOs are seeing an increasing level of private sector involvement through avenues such as board membership and partnership agreements. This increasing private sector involvement helps to ensure that the priorities of the government of a country are implemented in ways that supports tourism businesses and makes use of the expertise and resources of a private-sector dominated industry.

In most countries, the tourism industry is seen as a legitimate area for the involvement of government in what is otherwise a private sector dominated industry. The extent of government involvement differs between states, reflecting diverse political ideologies, the local historical development of the tourism industry, and the national significance of tourism. In countries whose governments are influenced by the prevailing neoliberal agenda in the West, state involvement in tourism is being reduced in the wake of the economic crisis and the rationale for public sector involvement in the tourism industry is weak. However, in countries with strong centralized states, such as China, the state plays a significant role in the development of the national tourism industry. Regardless of the degree of engagement, Government's day to day involvement in tourism is normally carried out through National Tourism Offices (NTOS). NTOs are the organisations responsible for the promotion of a country's national tourism industry and, in some cases, for the management of the development of that industry. NTOs are distinct from National Tourism Authorities (NTAs), such as ministries for tourism, in that an NTA will have wider responsibilities than then the NTO and will normally form a part of a government department. NTOs are normally tasked with implementing and supporting tourism policy aims that have been expressed by an NTA.

The functions of NTOs vary between countries. However, it is possible to identify core functions of NTOs that are common in many national contexts.

Many NTOs play a significant role in collecting statistical information on national tourism industries, including numbers of inbound and outbound tourists, measurements of spending and the other impacts of tourism and the publication of reports on issues affecting the sector.

Because NTOs and NTAs are normally separate organisations, NTOs do not normally make and publish tourism policy themselves. However, they will often be one of the most significant stakeholders in the policy making process. Due to an NTO's role in implementing national tourism policy and in carrying out research into the national tourism industry, it will be able to offer specialist insight in to the formulation of tourism policy. In some cases, NTOs formally advise governments on tourism policy.

Destination marketing is a core function of NTOs, with this role split between the promotion of inbound tourism and support for domestic tourism. Most NTOs focus on promoting inbound tourism through international tourism marketing campaigns, but the promotion of domestic tourism is seen as increasingly important, especially in the traditional tourist-generating countries in the West, as NTOs seek to maximize the local economic impacts of tourism spending.

NTOs are often involved in new tourism product development, as well as the support of existing tourism products and services, such as Tourist Information Centres and publically-funded tourist attractions and facilities. In terms of product development, NTOs will often be consultees in the planning process for new developments such as resorts and large visitor attractions, and will sometimes manage funding streams aimed at supporting innovation and development in the tourism industry. 
Although there is a trend towards NTOs becoming more independent of government, and having a less controlling role in national tourism industries, a number of NTOs have responsibility for the maintenance of national standards in tourism and, in some cases, for the administration of tourismspecific legislation and regulation. For example, in England, Visit England manages the national quality ratings system for hotels and, in Thailand, all tourism businesses must obtain a license from the Tourist Authority of Thailand.

Almost all NTOs are created by the public sector, although many of them include funding and other resource commitments from the private sector. Many NTOs have representation from the private sector in their governance. Private sector involvement in NTOs is increasingly common, offering opportunities for dialogue between the public and private sectors of tourism. A prominent critique of public sector dominated NTOs has been their lack of industry engagement and the implication that politics has too strong an influence on the functions of the organization, undermining its ability to support a private-sector dominated industry. Many contemporary NTOs are now constituted as armslength organisations, or public corporations, allowing them to operate with a degree of independence from government and to work more closely in partnership with key tourism industry stakeholders.

See Also: Politics and Tourism; Tourism Policies; Destination Management; Politics and Tourism; Government Subsidies

\section{Further Readings}

Ambrosie, L. "Tourism Policy Research: Avenues for the Future." International Journal of Tourism Policy v.3/1 (2010)

Edgell, David L. Sr. \& Swanson, Jason R. Tourism Policy and Planning: Yesterday, today and tomorrow. Abingdon: Routledge, 2013

Hall, C. Michael. Tourism Planning: Policies, Processes and Relationships. Harlow: Pearson Prentice Hall, 2008

Hall, C. Michael \& Jenkins, John, M. Tourism and Public Policy. Abingdon: Routledge, 1995

Lennon, J., Smith, H., Cockerell, N. \& Trew, J. Benchmarking National Tourism Organisations and Policies. Abingdon: Routledge

Zahra, Ann \& Ryan, Chris "National Tourism Organisations - Politics, Functions and Form: A New Zealand Case study" Anatolia, An International Journal of Tourism and Hospitality Research v.16/1 (2005).

James Kennell, University of Greenwich, London, UK 